Goldschmidt 2021 Abstract

https://doi.org/10.7185/gold2021.8016

\section{Titanite composite grain as an evidence of alkaline granite evolution}

$$
\begin{aligned}
& \text { BORIS V. BELYATSKY }{ }^{1} \text {, NICKOLAY RODIONOV } \\
& \text { ELENA LEPEKHINA } \\
& \text { ENTON ANTONOV } \\
& \text { ENANDREY } \\
& \text { ARZAMASTSEV }^{3} \text { AND SERGEY SERGEEV }
\end{aligned}
$$

\section{${ }^{1}$ VSEGEI,CIR}

${ }^{2}$ A.P.Karpinsky Russian Geological Research Institute

${ }^{3}$ Institute of Precambrian Geology \& Geochronology RAS

Presenting Author: bbelyatsky@mail.ru

The Baltic Shield is one of the world's largest ( $\left.c a 2500 \mathrm{~km}^{2}\right)$ provinces of alkaline granites which are confined to the Keivy segment of the Kola fold system and are represented by three series of mantle-source rocks of different origin, but close in time of formation linked to the Late Archaean mantle plume (Vetrin, 2018).

We have studied by SHRIMP-II the U-Pb system of titanite from the Western Keivy and Ponoy massifs of alkaline granitoids. The studied titanite is represented by irregular-shaped fragments of crystals up to $400-500 \mathrm{mkm}$ which have wellpronounced growth zoning, both oscillatory and sectorial, and contain microinclusions of accessory and rock-forming minerals. The grain partial recrystallization with unconformity to crystal forms is also noted. All studied titanites were characterized by insignificant variations in $\mathrm{U}$ within $10-100 \mathrm{ppm}$, whereas $\mathrm{Th} / \mathrm{U}$ varied from 0 to 13 , and non-radiogenic $\mathrm{Pb}$ from 0.1 to $60-70 \%$. Nevertheless, all calculated ages turned out to be concardant within the error limits after correction by the non-radiogenic $\mathrm{Pb}$ and grouped around two figures: 2700 and 1750 Ma (Figure). The temperature of the U-Pb system closing is comparable to the crystallization temperature of granite melts $\left(600-800^{\circ} \mathrm{C}\right)$, which makes it possible to correspondence the U-Pb age of titanite with the primary crystallization of alkaline granite massifs at 2710 $\mathrm{Ma}$, but the latest titanite formed at about $1750 \mathrm{Ma}$ reflects the influence of the tectonometamorphic paleoproterozoic event widespread on the Kola Peninsula. These estimations are well supported by single local age determinations on zircon inclusions in titanite.

Figure. $\mathrm{U}-\mathrm{Pb}$ concordia diagram for titanites from alkaline granite of Keivy, Kola peninsula, with BSE image of composite titanite grain with zircon inclusion.

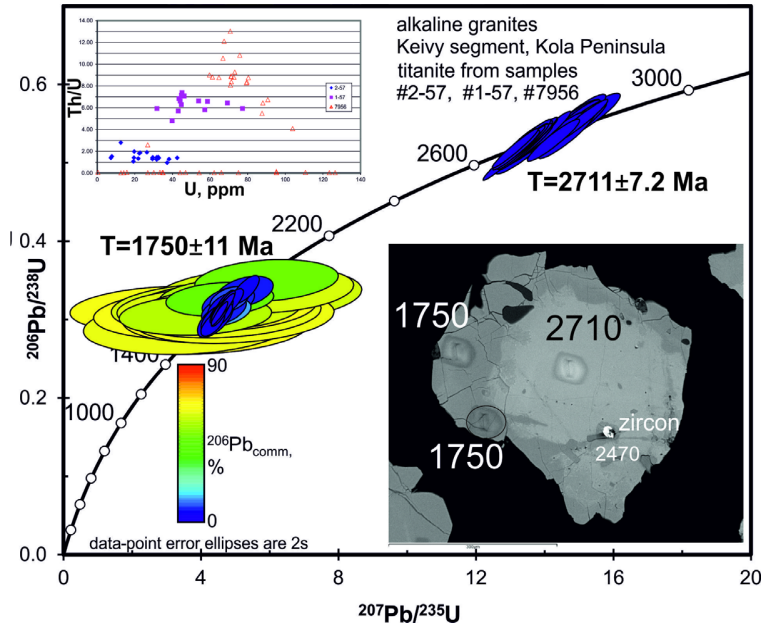

